\title{
Sphaeroplast Formation in Yeast During the Transition from Exponential Phase to Stationary Phase
}

\author{
By C. E. DEUTCH* AND J. M. PARRY \\ Department of Genetics, University College of Swansea, \\ Singleton Park, Swansea
}

(Received 29 June 1973; revised 20 August 1973)

\begin{abstract}
SUMMARY
The sensitivity of Saccharomyces cerevisiae to sphaeroplast formation has been examined during the transition from the exponential phase of growth to the stationary phase. Exponential-phase yeasts are sensitive to sphaeroplast formation while stationary yeasts are resistant. During the transition period, there is a rapid increase in resistance to sphaeroplast formation. This increase can be inhibited by treatment with either cycloheximide or 5-fluorouracil. It is suggested that the resistance to sphaeroplast formation characteristic of stationary-phase yeasts is the result of a specific modification of the yeasts during the transition period which is dependent on both RNA and protein synthesis.
\end{abstract}

\section{INTRODUCTION}

The wall of Saccharomyces cerevisiae is a complex structure composed of lipids, polysaccharides (mannans, glucans) and proteins (Northcote \& Horne, I952). Osmotically sensitive sphaeroplasts can be obtained by degrading the wall with enzyme mixtures obtained from either the gut of Helix pomatia (Eddy \& Williamson, 1957) or micro-organisms (Garcia Mendoza \& Villanueva, I962; Shapiro, Grossman, Marmur \& Kleinschmidt, I968; Mann, Heintz \& Macmillan, 1972). Such sphaeroplasts provide a useful experimental system for studies on nucleic acid metabolism (Hutchison \& Hartwell, 1967) or cell-well metabolism (Nečas, 1971). Also, they may serve as an important preparative stage in the isolation of mitochondria (Duell, Inoue \& Utter, 1964), nuclei (Wintersberger, Smith \& Letnansky, 1973) or unsheared DNA (Blamire, Cryer, Finkelstein \& Marmur, 1972; Petes \& Fangman, I972).

However, the sensitivity of yeast cells to sphaeroplast formation varies from strain to strain (Rost \& Venner, I965), and even within a particular strain it is highly dependent on the physiological state of the yeasts. Young yeasts from the exponential phase of growth can be converted to sphaeroplasts quite easily, but older or stationary-phase yeasts tend to be resistant to sphaeroplast formation (Duell et al. 1964; Brown, I97I; Shahin, I972). Such differences in sensitivity may be due to variations in the structure of the wall. Sometimes yeasts may be rendered more sensitive to sphaeroplast formation by treatment with thiol reagents such as thioglycollate (Kôvac, Bednarova \& Greksak, 1968), 2-mercaptoethanol (Darling, Theilade \& Birch-Anderson, 1969) or dithiothreitol (Sommers \& Lewis, I97I). It has therefore been suggested that the presence or absence of disulphide bonds within the protein component of the wall affects the penetration of the degradative enzymes and thus the sensitivity to sphaeroplast formation (Anderson \& Millbank, r966).

* Present address: Department of Molecular Biology, Albert Einstein College of Medicine, Bronx, New York I046I, U.S.A. 
In order to understand better the factors controlling sensitivity to sphaeroplast formation, we have examined the sensitivity of yeast to snail extract during the transition from the exponential phase of growth to the stationary phase. We describe experiments indicating that yeast becomes resistant to sphaeroplast formation during a narrow segment of the transition period, and that acquisition of this resistance can be blocked with cycloheximide, an inhibitor of protein synthesis.

\section{METHODS}

Organisms and culture conditions. Most of the experiments described were performed with 2NJ, a diploid strain of Saccharomyces cerevisiae which has the genotype: a/ $\alpha$, ade2-cI/+. For comparative purposes, the following strains were also used: $20 / 20(\mathrm{a} / \alpha$, ade 2 -cI $/ \mathrm{ade} 2-\mathrm{cI})$ and $\alpha$ wt $\times$ SI $795 \mathrm{~A}(\mathrm{a} / \alpha$, his $4 /+$, ura $/+$, trp5 $/+$, ade $6 /+)$. These last two diploids were constructed in this laboratory from haploid strains obtained from Dr R. Woods and Dr R. Mortimer respectively. Yeasts were grown in the liquid yeast-complete (YC) medium of Cox $\&$ Bevan (1962) either in a $28^{\circ} \mathrm{C}$ warm room with aeration by bubbling air from an aquarium pump, or in a Griffin \& George shaker-incubator at $28^{\circ} \mathrm{C}$. In general, cultures were inoculated at a concentration of $\mathrm{I} \times 1 \mathrm{IO}^{3}$ yeasts $/ \mathrm{ml}$ from a single colony on a YC plate, grown overnight and sampled the following day at concentrations between $5 \times 10^{6}$ and $5 \times 10^{8}$ yeasts $/ \mathrm{ml}$.

Cell counts. All cell counts were performed with a haemocytometer. None of the strains used shows any appreciable clumping under the growth conditions described. Buds were scored separately but included in the total cell count.

Sphaeroplast formation. Yeasts were converted to sphaeroplasts by the method of Hutchison \& Hartwell (I967), by using an enzyme mixture from Helix pomatia (L'Industrie Biologique Française, Gennevilliers, France 'special' for the hydrolysis of cellular membranes) at a concentration of $2 \%(\mathrm{v} / \mathrm{v})$. The formation of sphaeroplasts was measured quantitatively by a modification of the procedure described by Blamire et al. (1972). A sample of the yeastenzyme mixture was diluted $\mathrm{I}$ : Io with distilled water, detergent (Sarkosyl NL $35,2 \% \mathrm{v} / \mathrm{v}$ ) was added, and the solution mixed briefly with a vortex mixer. Intact yeasts were then counted with a haemocytometer, and will be referred to in this paper as 'lysis-resistant cells'. This dilution-detergent treatment had no effect on either exponential- or stationaryphase yeasts which had not been exposed to the enzyme mixture. Sensitivity to sphaeroplast formation is expressed as the percentage of lysis-resistant cells remaining after enzyme treatment. For one experiment, a mushroom extract, prepared as described by Bevan \& Costello (1964), was used as the source of wall-degrading enzymes.

Determination of $D N A, R N A$, and protein contents. Samples containing approximately $\mathrm{IO}^{9}$ yeasts were removed from growing cultures and growth was stopped by adding formalin to a concentration of $2 \%(\mathrm{v} / \mathrm{v})$. Yeasts were harvested by centrifugation, washed once with distilled water, and the yeast pellet frozen at $-20^{\circ} \mathrm{C}$. The pellets were later thawed and extracted by the following modification of the procedure of Parry \& Cox (I972). The yeasts were extracted twice with $2.5 \mathrm{ml} 10 \%(\mathrm{w} / \mathrm{v})$ trichloroacetic acid (TCA) for $20 \mathrm{~min}$ at $0{ }^{\circ} \mathrm{C}$, washed twice with $95 \%$ ethanol, extracted three times with $\mathrm{I} \cdot 0 \mathrm{ml} 5 \%(\mathrm{v} / \mathrm{v})$ perchloric acid (PCA) for $20 \mathrm{~min}$ at $70^{\circ} \mathrm{C}$, washed twice with $95 \%$ ethanol, and extracted twice with $\mathrm{I} \cdot 5 \mathrm{ml}$ I N-NaOH for $30 \mathrm{~min}$ at $60^{\circ} \mathrm{C}$. The PCA extracts were pooled and assayed for DNA by the diphenylamine method of Burton (I956), and for RNA by the orcinol method (Schneider, 1957), with calf thymus DNA and yeast RNA as the respective standards. The $\mathrm{NaOH}$ extracts were combined and assayed for protein by the method of Lowry, Rosebrough, Farr \& Randall (I95I) with bovine serum albumin as the standard.

Chemicals. Except where noted, all chemicals were obtained from BDH Chemicals Ltd, 
Godalming, Surrey. Cycloheximide was obtained from Koch-Light Laboratories, Colnbrook, Buckinghamshire, and 5-fluorouracil from Serva Feinbiochemica GMBH, Heidelberg, Germany. Sarkosyl NL35 was a gift from Ciba-Geigy Basle, Switzerland.

\section{RESULTS}

Relative sensitivity of exponential-phase and stationary-phase cells to sphaeroplast formation

To determine their sensitivity to sphaeroplast formation, exponential-phase and stationaryphase cells of Saccharomyces cerevisiae strain $2 \mathrm{NJ}$ were treated with an extract of Helix pomatia for different lengths of time. After $15 \mathrm{~min}$ of treatment of exponential-phase yeasts, less than $0.1 \%$ of the yeasts were lysis-resistant. This decrease in resistance to lysis by Sarkosyl NL 35 correlated well with the conversion of the yeasts to sphaeroplasts as determined microscopically. When stationary-phase yeasts were treated with the snail extract, about $80^{\circ}$ of the cells remained lysis-resistant after 60 min of enzyme treatment; no further conversion to sphaeroplasts occurred with treatment up to $180 \mathrm{~min}$. This observation is in agreement with that previously reported by Blamire et al. (1972). The exact percentage of stationary-phase yeasts which remained lysis-resistant varied somewhat from experiment to experiment (between 50 and $80 \%$ ), and was partly dependent on the batch of snail extract used. For the remaining experiments described here, the yeasts were exposed to snail extract for a fixed period of $60 \mathrm{~min}$ at $37^{\circ} \mathrm{C}$. Under these conditions, exponential-phase cells were completely sensitive to sphaeroplast formation (o \% lysis-resistant cells) and stationary phase cells were highly resistant to sphaeroplast formation (50 to $80 \%$ lysis-resistant cells).

The large difference in the sensitivity of exponential-phase and stationary-phase yeasts to sphaeroplast formation suggests that the difference was the result of physiological changes occurring during the transition from one phase to the other. It seems unlikely that this difference in sensitivity was the result of the selective overgrowth of a small genetically determined resistant fraction as the yeasts entered stationary phase. To eliminate this possibility, the lysis-resistant yeasts remaining after detergent treatment of stationary-phase cells, which had been exposed to snail extract for $180 \mathrm{~min}$, were streaked on to a YC plate. Five of the isolated colonies which appeared were used to inoculate fresh liquid cultures. These cultures were grown to the exponential phase and tested for sensitivity to sphaeroplast formation. All five cultures were completely sensitive to sphaeroplast formation.

\section{Sensitivity to sphaeroplast formation during the transition from exponential phase to stationary phase}

To study the difference between exponential-phase yeasts and stationary-phase yeasts in more detail, the sensitivity of strain $2 \mathrm{NJ}$ to sphaeroplast formation was tested periodically during the transition from one phase to the other (Fig. I). After a period of balanced exponential growth, in which total cell counts, DNA, RNA, and protein increased at the same rate (doubling time of $72 \mathrm{~min}$ ), the culture entered a transition period. This period began approx. $22 \mathrm{~h}$ after inoculation under these growth conditions (at about the $4 \mathrm{~h}$ point in Fig. I), and lasted 8 to $9 \mathrm{~h}$. During this period, RNA synthesis decreased first, followed by parallel decreases in DNA synthesis, protein synthesis, and total cell counts. These decreases were accompanied by a gradual decrease in the percentage of budding yeasts in the population. During this transition period, there was a sharp increase in the percentage of lysisresistant yeasts in the culture, which began when the percentage of budding yeasts had dropped to about $70 \%$. This increase in resistance to sphaeroplast formation occurred over a period of about $4 \mathrm{~h}$, and consisted of two phases : a very rapid initial increase to about $50 \%$ 


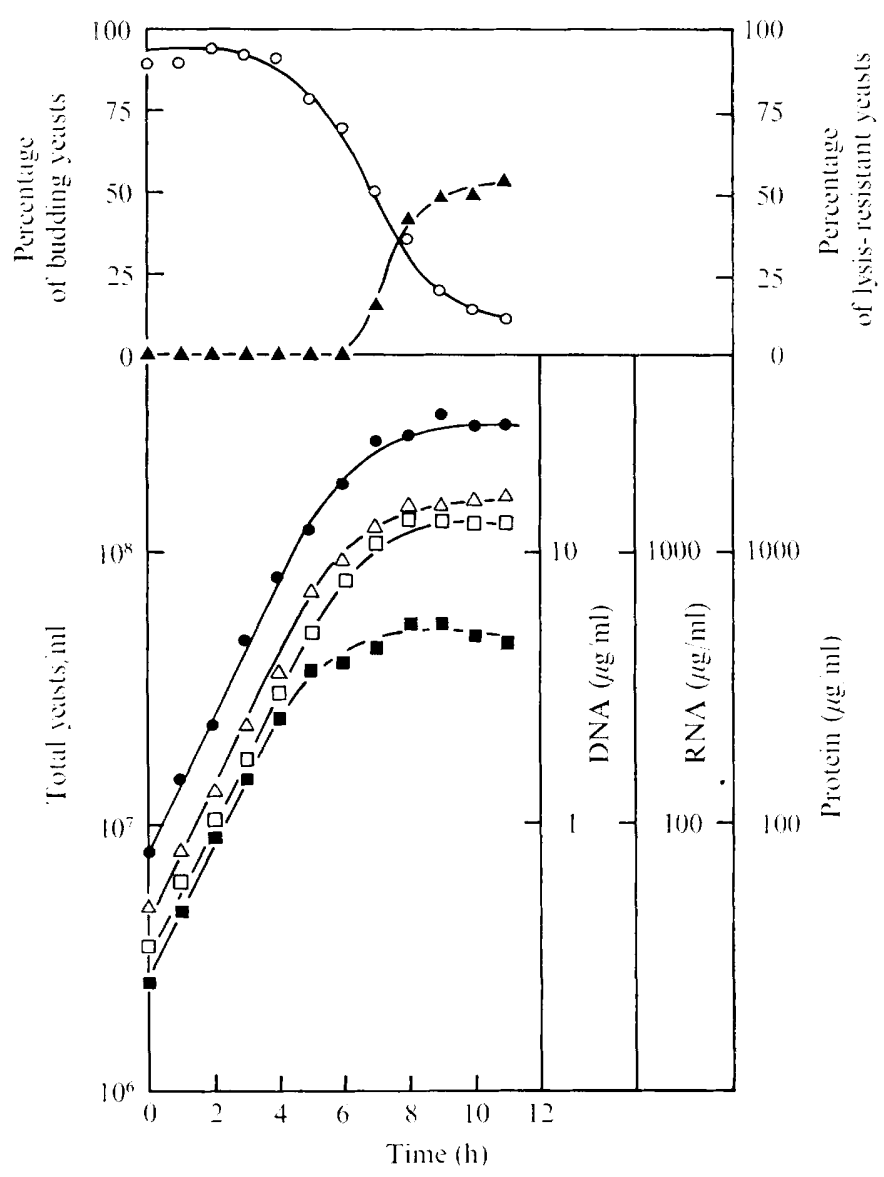

Fig. I. Sensitivity to sphaeroplast formation during the transition from exponential phase to stationary phase. The lower half (log scale) indicates total cells/ml (๑), DNA content/ml ( $\square$ ), RNA content $/ \mathrm{ml}(\boldsymbol{\square})$, and protein content $/ \mathrm{ml}(\triangle)$. The upper half (linear scale) indicates percentage of budding yeasts $(O)$ and percentage of lysis-resistant yeasts $(\boldsymbol{A})$.

lysis-resistant cells, followed by a more gradual increase until the final level of resistance was achieved (about $70 \%$ in this experiment).

Sensitivity to sphaeroplast formation was apparently not directly related to whether the cells were budding or not. Early in the transition period, there were non-budding yeasts which were completely sensitive to sphaeroplast formation. Microscopic examination of the lysis-resistant fraction indicated that while the first lysis-resistant yeasts to appear may have been non-budding yeasts, in a short time budding yeasts made up a substantial portion of the lysis-resistant fraction. Sometimes the mother cell lysed while the bud was lysis-resistant.

\section{Effect of cycloheximide on sensitivity to sphaeroplast formation}

One possible explanation for the rapid increase in lysis-resistant yeasts as cultures approach the stationary phase is that sensitivity to sphaeroplast formation is dependent on the continual synthesis of a particular wall protein or enzyme. It might be supposed that as protein synthesis ceases when the cells enter stationary phase, this protein would no longer be made and the yeasts would become resistant to sphaeroplast formation. A candidate for 


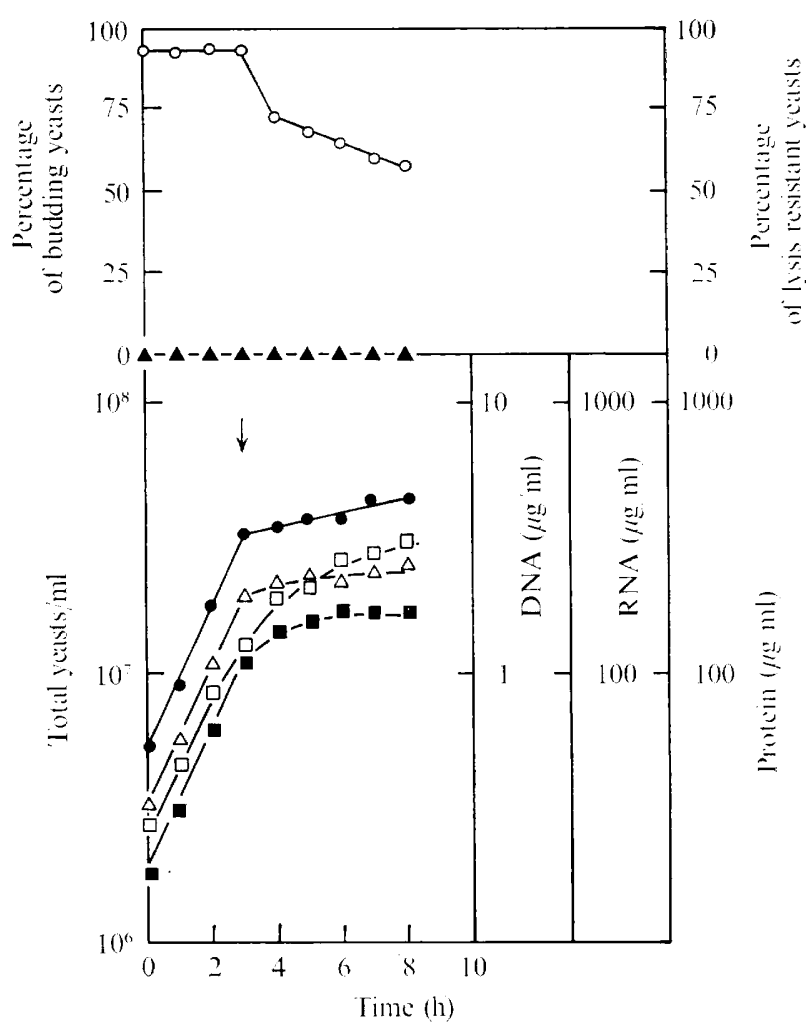

Fig. 2. Effect of $\mathrm{I} \mu \mathrm{g}$ cycloheximide $/ \mathrm{ml}$ on exponential-phase yeasts. Cycloheximide added at time indicated by arrow. Symbols as in Fig. I.

this protein would be the enzyme protein-disulphide reductase described by Nickerson \& Falcone (I956), which is known to reduce disulphide bonds in wall proteins. Maintenance of these bonds in a reduced state might keep the cells sensitive to sphaeroplast formation. This hypothesis would be consistent with the observation that thiol reagents which reduce disulphide bonds may render yeasts more sensitive to sphaeroplast formation (Anderson \& Millbank, 1966).

As a test of this hypothesis, exponential-phase yeasts were treated with I $\mu$ g cycloheximide/ $\mathrm{ml}$, an inhibitor of protein synthesis (Kerridge, I958). If the hypothesis is correct, the treated yeasts should become resistant to sphaeroplast formation. The results indicated that they did not (Fig. 2). Cycloheximide inhibited protein synthesis almost completely within about 60 min. It partially inhibited RNA and DNA synthesis, caused a decrease in the percentage of budding yeasts, and reduced the rate of increase in total cell count. However, the percentage of lysis-resistant cells remained at $0 \%$.

An alternative explanation is that something must be made during the transition period which in some way confers resistance to sphaeroplast formation on the yeasts. To test whether protein synthesis might be required for this process, a culture of strain $2 \mathrm{NJ}$ was grown to the transition period as before. Periodically, samples were removed and cycloheximide ( $\mu \mathrm{g} / \mathrm{ml}$ ) was added. Incubation of the control culture and the cycloheximide-treated subcultures was continued and the sensitivity to sphaeroplast formation of each tested periodically (Fig. 3). In the control culture, a rapid increase in resistance to sphaeroplast 


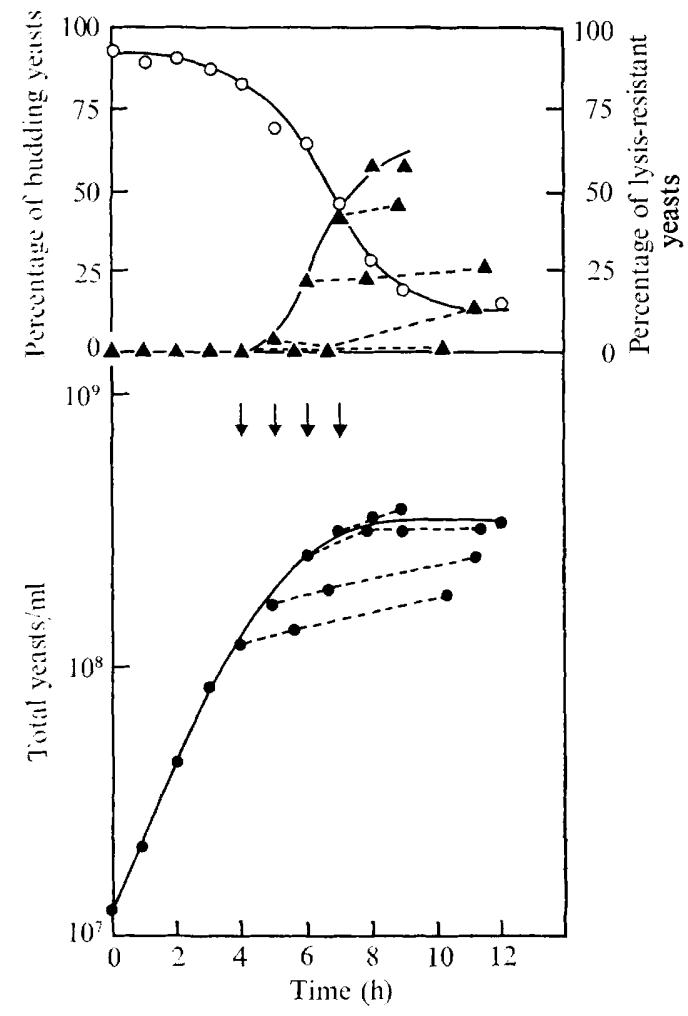

Fig. 3. Effect of $\mathrm{I} \mu \mathrm{g}$ cycloheximide/ml on sphaeroplast formation during the transition period. At the times indicated by the arrows, samples of the culture were removed, cycloheximide added, and incubation continued. The lower half (log scale) indicates total yeasts/ml (๑). The upper half (linear scale) indicates percentage of budding yeasts $(\bigcirc)$ and percentage of lysis-resistant yeasts $(\boldsymbol{\Delta})$.

formation was observed similar to that shown in Fig. I. Each of the cycloheximide-treated subcultures, on the other hand, exhibited essentially the same sensitivity to sphaeroplast formation as it did when the cycloheximide was added. Any further increase in lysis-resistant yeasts was inhibited, even if the cultures were incubated beyond the point where the control culture exhibited maximal resistance to sphaeroplast formation. A small increase in total cell count may have occurred during this time. These results suggest that the acquisition of resistance to sphaeroplast formation was dependent on continual protein synthesis during the transition period.

If sensitivity to sphaeroplast formation is related to protein synthesis in this way, one might predict that with lower concentrations of cycloheximide, which only partially inhibit protein synthesis, a partial increase in lysis-resistant cells should occur. To test this prediction, a culture of strain $2 \mathrm{NJ}$ was grown to the point where the rapid increase in lysis-resistant yeasts would normally occur (about the position of the second arrow in Fig. 3). The sensitivity of the yeasts to sphaeroplast formation at this point and the protein content of the culture were determined. A series of subcultures was set up containing different concentrations of cycloheximide, and incubated for an additional $2 \mathrm{~h}$. The sensitivity to sphaeroplast formation and the protein content of each subculture were then determined again. The increase in lysis-resistant yeasts and the increase in protein content were plotted as a function 


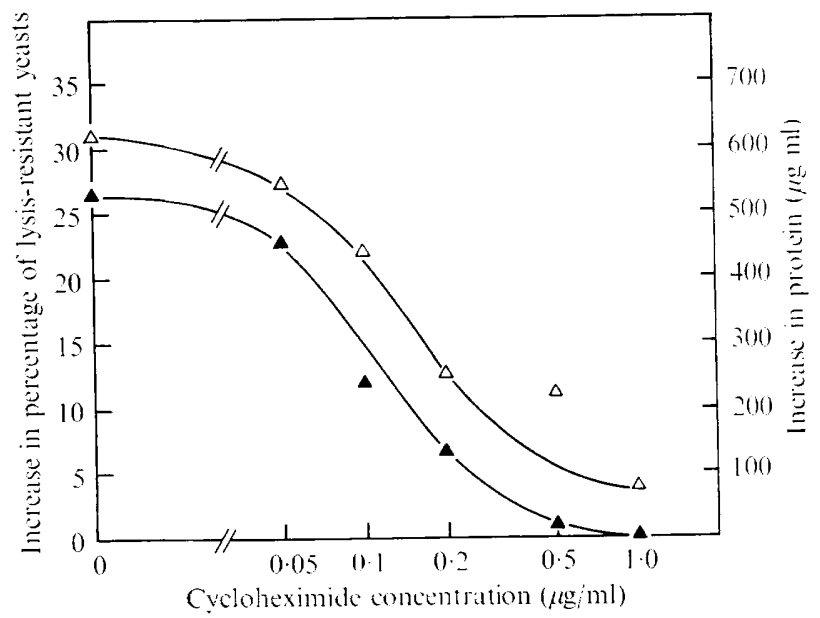

Fig. 4. Effect of different concentrations of cycloheximide (log scale) on protein synthesis $(\triangle)$ and sensitivity to sphaeroplast formation $(\mathbf{\Delta})$.

of the cycloheximide concentration (Fig. 4). Cycloheximide affected both characteristics in a parallel way.

A small increase in protein content still occurred in the presence of $\mathrm{I} \mu \mathrm{g}$ cycloheximide $/ \mathrm{ml}$. These experiments have been repeated with higher concentrations of cycloheximide (up to 10 $\mu \mathrm{g} / \mathrm{ml}$ ) which inhibited protein synthesis completely. Under these conditions, any increase in lysis-resistant cells was still inhibited.

\section{Sphaeroplast formation with mushroom extract}

To determine if the rapid increase in lysis-resistant yeasts during the transition period and the effect of cycloheximide on it were in some way unique to sphaeroplasts formed with snail extract, the experiment shown in Fig. 3 was repeated with an extract of the common commercial mushroom as a source of degradative enzymes (Bevan \& Costello, I964). The mushroom extract was much less effective than the extract from Helix pomatia. When exponential-phase yeasts were treated with a $10 \%$ (v/v) solution, only about 40 to $50 \%$ were converted to sphaeroplasts in $60 \mathrm{~min}$ at $37^{\circ} \mathrm{C}$. When stationary-phase yeasts were treated in a similar way, none of the cells were converted to sphaeroplasts. Nevertheless, the difference between the response of the yeasts from the two phases was great enough to permit an examination of sphaeroplast formation during the transition period.

A culture of strain $2 \mathrm{NJ}$ was grown to the transition period and samples treated with $\mathrm{I} \mu \mathrm{g}$ cycloheximide/ml as in the experiment shown in Fig. 3. A rapid increase in lysis-resistant yeasts was again observed in the control culture at the beginning of the transition period. This increase occurred somewhat earlier than that observed with yeast treated with snail extract, and began just as the percentage of budding cells had begun to drop. All of the yeasts became lysis-resistant in about $2 \mathrm{~h}$. This increase in lysis-resistance was again not related to budding, since it was completed before the percentage of budding yeasts in the population had dropped appreciably.

The effect of cycloheximide on sensitivity to sphaeroplast formation was somewhat more complex that that observed with snail extract. About half of the total increase in lysisresistant cells (from 40 to $70 \%$ ) could occur in the presence of I $\mu \mathrm{g}$ cycloheximide $/ \mathrm{ml}$. 
Table I. Effect of 5-fluorouracil on sensitivity to sphaeroplast formation, RNA synthesis and protein synthesis

$\begin{array}{cccc}\begin{array}{c}\text { Concentration } \\ (\mu \mathrm{g} / \mathrm{ml})\end{array} & \begin{array}{c}\text { Increase in } \% \\ \text { lysis-resistant } \\ \text { yeasts }\end{array} & \begin{array}{c}\text { Increase in } \\ \text { RNA }(\mu \mathrm{g} / \mathrm{ml})\end{array} & \begin{array}{c}\text { Increase in } \\ \text { protein }(\mu \mathrm{g} / \mathrm{ml})\end{array} \\ 0 & 31 \cdot 5 & 150 & 720 \\ 6 \cdot 25 & 7 \cdot 0 & 150 & 685 \\ 25 & 4 \cdot 1 & 130 & 630 \\ 100 & 2 \cdot 3 & 65 & 560\end{array}$

However, the additional increase up to $100 \%$ was blocked if protein synthesis was inhibited in this way. The results of this experiment were thus qualitatively similar to those obtained with snail-extract treatment.

\section{Sphaeroplast formation in other diploid strains of yeast}

To determine if these results were unique to Saccharomyces cerevisiae strain $2 \mathrm{NJ}$, experiments similar to that shown in Fig. 3 were performed with two other diploid strains of yeast. A rapid increase in lysis-resistant yeasts during the transition period was observed with both strain $20 / 20$ and strain $\alpha w t \times S 1795 \mathrm{~A}$. With strain $20 / 20$, the point where this rapid increase occurred was somewhat earlier than in strain $2 \mathrm{NJ}$, and with strain $\alpha \mathrm{wt} \times \mathrm{SI} 795 \mathrm{~A}$ somewhat later than strain $2 \mathrm{NJ}$. Similar final levels were achieved in all three strains. The increase in lysis-resistant yeasts could be inhibited by I $\mu$ g cycloheximide $/ \mathrm{ml}$ in strain $20 / 20$ and strain

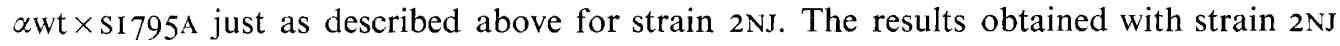
were therefore not simply a strain-specific effect.

\section{Effect of 5-fluorouracil on sensitivity to sphaeroplast formation}

The increase in lysis-resistant yeasts during the transition period appears to be dependent on protein synthesis. The possibility that there is a similar dependence on RNA synthesis was investigated by performing an experiment similar to that described in Fig. 4 using 5fluorouracil as an inhibitor of RNA synthesis. This base analogue has a wide range of effects, but particularly appears to disrupt normal ribosome assembly in yeast (de Kloet, I968).

A culture of strain $2 \mathrm{NJ}$ was grown to the point where the rapid increase in lysis-resistant yeasts would normally occur, and a series of subcultures set up containing different concentrations of 5-fluorouracil. Percentage of lysis-resistant cells, RNA content, and protein content were measured immediately and again after $2 \mathrm{~h}$ of incubation. The normal increase in lysis-resistant yeasts was inhibited at all the concentrations tested (Table I). RNA and protein synthesis were reduced at the highest concentration used ( $100 \mu \mathrm{g} / \mathrm{ml})$, but were not appreciably affected at the lowest concentration $(6 \cdot 25 \mu \mathrm{g} / \mathrm{ml})$ which still reduced the increase in resistance to sphaeroplast formation by $75 \%$. This was perhaps to be expected since, to be effective, 5 -fluorouracil need not inhibit synthesis.

\section{DISCUSSION}

The results indicate that there is a rapid increase in the resistance of yeasts to sphaeroplast formation during the transition from exponential phase to stationary phase. This increase occurs over a relatively narrow segment of the total transition period and is not related to whether the yeasts are budding or not. The increase in resistance can be inhibited with 
cycloheximide or 5-fluorouracil, suggesting that the resistance to sphaeroplast formation characteristic of stationary phase yeast is the result of a specific modification of the yeasts which is dependent on RNA and protein synthesis.

The increase in resistance to sphaeroplast formation in these experiments appears as a fairly sharp transition point. This is partly a consequence of using an all-or-none assay for sphaeroplast formation. With the dilution-detergent treatment, a yeast either lyses or not. Although more cell 'ghosts' were observed microscopically during the transition period than with exponential-phase yeasts, these 'ghosts' were not scored as lysis-resistant cells. The actual period in which modification of the yeasts occurs is therefore probably longer than the transition point itself. However, the sharpness of the transition point does suggest that this modification is a process which occurs in all the yeasts more or less simultaneously. It was observed that the maximum level of $100 \%$ lysis-resistant yeasts was never reached with snail extract-treated cells. This may be because the modification resulting in resistance to sphaeroplast formation takes place at a time when overall RNA and protein synthesis are gradually being reduced. Whether an individual yeast becomes resistant probably depends on the relative rates of these processes in that yeast.

Several possible types of modification could result in increased resistance to sphaeroplast formation. Disulphide bonds within the wall proteins have been considered important, and it is possible that new enzymes are synthesized during the transition period which catalyse the formation of such bonds within the existing wall. Alternatively, new wall proteins may be made at this time, perhaps containing more disulphide bonds, which are then incorporated into the wall. However, we have found that treatment of stationary-phase yeasts of strain 2 NJ with thioglycollate or dithiothreitol does not greatly increase their sensitivity to sphaeroplast formation. Other types of modification of the wall, such as more extensive crosslinking of the polysaccharide components or the formation of new types of bonds, may therefore be involved. Also, it is possible that inhibition of the enzymes involved in autolysis may alter sensitivity to sphaeroplast formation.

A partial increase in resistance to sphaeroplast formation with mushroom extract-treated cells occurred in the presence of cycloheximide. It is possible therefore that the modifications discussed above utilize enzymes or other proteins which are present in exponential-phase yeasts but which exhibit increased activity during the transition period. The effect of inhibitors suggests that this increased activity is due in part to de novo RNA and protein synthesis rather than to an activation or inhibition of pre-existing proteins. The change in sensitivity to sphaeroplast formation may therefore be the result of the transcription and translation of specific genes during the transition period.

This work was supported under contract BIO E II9-72-I from Euratom. We thank Dr D. H. Williamson for helpful discussions.

\section{REFERENCES}

Anderson, F. B. \& Millbank, J. W. (I966). Protoplast formation and yeast cell wall structure. The action of the enzymes of the snail Helix pomatia. Biochemical Journal 99, 682-687.

Bevan, E. A. \& Costello, W. P. (1964). The preparation and use of an enzyme which breaks open yeast asci. Microbial Genetics Bulletin 2r, 5.

Blamire, J., Cryer, D. R., Finkelstein, D. B. \& Marmur, J. (I972). Sedimentation properties of yeast nuclear and mitochondrial DNA. Journal of Molecular Biology 67, I I-24.

Brown, J. P. (I 97I). Sensitivity of the cell walls of some yeasts to lysis by enzymes of Helix pomatia. Canadian Journal of Microbiology 17, 205-208. 
Burton, K. (1956). A study of the conditions and mechanism of the diphenylamine reaction for the colorimetric estimation of deoxyribonucleic acid. Biochemical Journal 62, 3I 5-323.

Cox, B. S. \& Bevan, E. A. (1962). Aneuploidy in yeast. New Phytologist 6r, 342-355.

Darling, S., Theilade, J. \& Birch-Anderson, A. (I969). Kinetic and morphological obsersations on Saccharomyces cerevisiae during spheroplast formation. Journal of Bacteriology 98, 797-810.

Duell, E. A., Inoue, S. \& UTter, M. F. (1964). Isolation and properties of intact mitochondria from spheroplasts of yeast. Journal of Bacteriology 88, $1762-1773$.

EdDy, A. A. \& Williamson, D. H. (I957). A method of isolating protoplasts from yeast. Nature, London I79, I 252-I 253 .

Garcia Mendoza, C. \& Villanueva, J. R. (1962). Production of yeast protoplasts by an enzyme preparation of Streptomyces sp. Nature, London 195, $1326-1327$.

Hutchison, H. T. \& HaRTwell, L. H. (I967). Macromolecule synthesis in yeast spheroplasts. Joumal of Bacteriology 94, I 697-1705.

KERRIDGE, D. (1958). The effect of actidione and other anti-fungal agents on nucleic acid and protein synthesis in Saccharomyces carlsbergensis. Journal of General Microbiology 19, 467-506.

DE KLOET, S. R. (1968). Effects of 5-fiuorouracil and 6-azauracil on the synthesis of ribonucleic acid and protein in Saccharomyces carlsbergensis. Biochemical Journal 106, I67-1 78.

Kôvac, L., Bednarova, H. \& GreksaK, M. (1968). Oxidative phosphorylation in yeast. I. Isolation and properties of phosphorylating mitochondria from stationary phase cells. Biochimica et biophysica acta I53, 32-42.

Lowry, O. H., Rosebrough, N. J., Farr, A. L. \& Randall, R. J. (I95I). Protein measurement with the Folin phenol reagent. Journal of Biological Chemistry 193, 265-275.

ManN, J. W., Heintz, C. E. \& Macmillan, J. D. (I972). Yeast spheroplasts formed by cell wall-degrading enzymes from Oerskovia sp. Journal of Bacteriology III, 82 I-824.

NeČAS, O. (197I). Cell wall synthesis in yeast protoplasts. Bacteriological Reviews 35, I49-I 70.

Nickerson, W. J. \& Falcone, G. (1956). Enzymatic reduction of disulfide bonds in cell wall protein of bakers' yeast. Science, New York 124, 318-319.

Northcote, D. H. \& Horne, R. W. (1952). The chemical composition and structure of the yeast cell wall. Biochemical Journal 5r, 232-236.

PARRY, E. M. \& CoX, B. S. (I972). The general properties of a strain of yeast with less DNA than normal. Journal of General Microbiology 70, 129-149.

Petes, T. D. \& Fangman, W. L. (1972). Sedimentation properties of yeast chromosomal DNA. Proceedings of the National Academy of Sciences of the United States of America 69, I $188-119 \mathrm{I}$.

Rost, K. \& VenNer, H. (1965). Enzymatische Zellwand verdauung bei Hefen durch Schneckenenzym. Archiv für Mikrobiologie 51, 122-129.

SCHNEIDER, W. C. (1957). Determination of nucleic acids in tissues by pentose analysis. In Methods in Enzymology vol. 3, pp. 680-684. Edited by S. P. Colowick and N. O. Kaplan. New York: Academic Press.

ShaniN, M. M. (1972). Relationship between yield of protoplasts and growth phase in Saccharomyces. Journal of Bacteriology 110, 767-771.

Shapiro, L. Grossman, L., I., Marmur, J. \& Kleinschmidt, A. K. (i968). Physical studies on the structure of yeast mitochondrial DNA. Journal of Molecular Biology 33, 907-922.

Sommers, A. \& LEWIS, M. J. (197I). Effect of dithiothreitol on yeast: spheroplast formation and invertase release. Journal of General Microbiology 69, 327-335.

Wintersberger, U., SMITH, P. \& LetNANSKy, K. (1973). Yeast chromatin: preparation from isolated nuclei, histone composition and transcription capacity. European Journal of Biochemistry 33, I I2-I 30. 